\title{
Waste Cooking Oil into Biodiesel Transformation and its Economical Potency through Circular Economic Model in Semarang Barat Area Indonesia
}

\author{
Arie Wicaksono ${ }^{1, *}$, Widayat ${ }^{1,2}$, Singgih Saptadi ${ }^{1,3}$ \\ ${ }^{1}$ Magister Program of Energy, School of Postgraduate Studies, Diponegoro University, Semarang - Indonesia \\ ${ }^{2}$ Chemical Engineering, Diponegoro University, Semarang - Indonesia \\ ${ }^{3}$ Industrial Engineering, Diponegoro University, Semarang - Indonesia
}

\begin{abstract}
The circular economic scheme is applied to utilize the waste cooking oil from semarang barat resident area as raw material of biodiesels, the results shown that biodiesels production was able to produce $82.54 \%$ of biodiesels yields and analyzed refer to Keputusan Direktur Jendral Minyak dan Gas Bumi No.13483K/24/DJM/2006 specification including FAME concentration, Flash Point, Density, Viscosity and calorie value. Based on the analysis, the biodiesel produced has the potential as a substitute for diesel oil used for boiler fuel. This scheme is able to generate net income of IDR 135,542,430 per year from the biodiesel utilization on the difference of diesel oil utilization for boiler fuel and IDR 14,928,656 per year from crude glycerol sales.
\end{abstract}

Keywords: Biodiesel; Circular Economy; Waste Cooking Oil.

\section{Introduction}

Biodiesel can be produced from agricultural, farming and waste products, particularly waste cooking oil (WCO) [1], Rate consumption of cooking oil per capita in 2015 was based on SUSENAS-BPS is $11.23 \mathrm{~kg} /$ capita, makes total domestic consumption for the year was 2.87 million tons of cooking oil or equivalent to 4.2 million tons of palm oil [2]. If that potential is fully developed into biodiesel, it will reduce domestic waste disposed into the environment, causing substantial drainage and edaphic pollution, , as well as high quantity Green House emission from the disposals to the environments [3]. Biodiesel is produced from natural oils or animal fats and alcohol, through a transesterification reaction, this chemical reaction converts triglycerides form esters better known as Fatty acid methyl esters (FAME) [2].

Literature review focus on economic studies related to the production of biodiesel with a variety of catalysts and technologies offered, one of them is biodiesel production with acid and alkaline that able to produce up to $94 \%$ yield [4]. It is Not so many articles that discuss the economic analysis aspect for the production of biodiesel fuel WCO, techno-economic studies using raw materials of $\mathrm{WCO}$ is done by [5] require large upfront investment as the process of using super-critical method. Simulation of the potential of biodiesel made from used cooking oil in beirut done by [6] at the laboratory scale production and calculate the market price of products with various sources of providers, shows that the biodiesel production to be economically competitive with fossil fuels. Incorporation of low-cost production process with the potential WCO source, biodiesel development process can be carried out at least for about waste reduction through its Corporate Social Responsibility program with the scheme circular economy in our neighborhood, while reducing pollution also gather profit.

Circular economy is an economy constructed from societal production-consumption systems that maximize the service produced from the linear nature-society-nature material and energy throughput flow. This is done by using cyclical materials flows, renewable energy sources and cascading type energy flows. A successful circular economy contributes to all the three dimensions of sustainable development. Circular economy limits the throughput flow to a level that nature tolerates and utilizes ecosystem cycles in economic cycles by respecting their natural reproduction rates [7]. The circular economy approach is supported by approaches based on resource- or eco-efficiency, sustainability, corporate social responsibility (CSR), the triple bottom line and so on, but these are not as systems-

\footnotetext{
* Corresponding author: witjaksonoarie@gmail.com
} 
focused and can probably be classed as encouraging strategies that are 'less bad', rather than 'more good' [8] The study aims at analysis of economic potential (circular economy) production of biodiesel made from WCO by utilizing the Corporate Social Responsibility lane factory in Semarang barat region to be recycled into biodiesel using a machine with a capacity of $50-70 \mathrm{~kg}$ per batch. The production of biodiesel is used to fuel the boilers, the profit potential fuel price difference with the existing circulate the resident in the neighborhood as WCO purchased scenario.

\section{Methods}

\subsection{Waste Cooking Oil (WCO)}

A scenario of the raw material intake of WCO is taken from the residents around the district of Semarang Barat, with a scheme of corporate cooperation through the program Corporate Social Responsibility of a company in the area. The approach of potential supply and raw material prices is conducted in a literature study approach.

\subsection{Biodiesel Production}

Biodiesel was produced using a machine belonging to Diponegoro University with a capacity of 50-70 liters. The process begins with a analysis of free fatty acid levels (FFA) using a method [9], when the level of FFA $<2 \%$ then the production process only carried out trans esterification process, instead the rate of FFA $>2 \%$ then the process of esterification first before proceeding to the trans esterification to lower FFA levels. Prior to the esterification or trans esterification of raw materials, fried oil is done filtering the raw materials of cooking oils with flannel to remove the coarse particles.

\subsubsection{Esterification Reaction}

Methanol $(1: 2,5)$ molar ratio to used WCO that has been mixed with $\mathrm{H}_{2} \mathrm{SO}_{4} 0.2 \%(\mathrm{~V} / \mathrm{V})$ against WCO, stirred with a continuous system at a temperature of $60 \pm 2{ }^{\circ} \mathrm{c}$ for 1 hour [4]. Separate the bottom layer for the trans esterification process.

\subsubsection{Trans Esterification Reaction}

Add raw material that has been through pretreatment or raw material with a level of FFA $<2 \%$ with methanol (1:4.5) molar ratio that has been dissolved by $\mathrm{KOH}$ as much as $1 \%$ $(\mathrm{w} / \mathrm{w})$. Stirred with a continuous system at a temperature of $60 \pm 2{ }^{\circ} \mathrm{c}$ for 2 hours [4]. Settled it on the tank for 24 hours to get a perfect separation. Separate the glycerol (bottom) and FAME (upper) parts, proceed to the washing process and distillation

\subsubsection{Washing and distillation}

FAME transesterification is washed with water $(1: 1) \mathrm{v} / \mathrm{v}$ with a washing temperature of $80 \pm 5^{\circ} \mathrm{C}$, up to the remaining water of clear wash. The washing results are distilled at $110 \pm 5{ }^{\circ} \mathrm{c}$ to eliminate residual water and the remaining methanol is collected for nexy batch biodiesel process. Calculate production yield by:

$$
\text { Yield }(\%)=\frac{\text { Amount FAME produced }}{\text { Amont Oil }} \times 100 \%
$$

\subsubsection{Standardization}

The result of FAME washing and distillation is measured according to Decree of the Director General of Oil and Gas No.13483K/24/DJM/2006 about the standards and specifications of Biofuels [10]

\subsection{Circular Economic Scenario}

Economic analysis is conducted by calculating the potential profit on the production of biodiesel through the circular economy scenario. Utilization of cooking oil waste into biodiesel through the program corporate social responsibility an industry in Semarang barat region, biodiesel products used to fuel the boiler steam factory with a capacity of 1 ton/hour with a fuel rate of $63.1 \mathrm{~L} / \mathrm{h}$ ( Diesel Fuel) [11]. Existing steam boilers used High-Speed Diesel fuel (HSD) as a fuel and the potential profit generated against the difference in the price of biodiesel production and HSD played to the community as a purchase of used cooking oil raw materials.

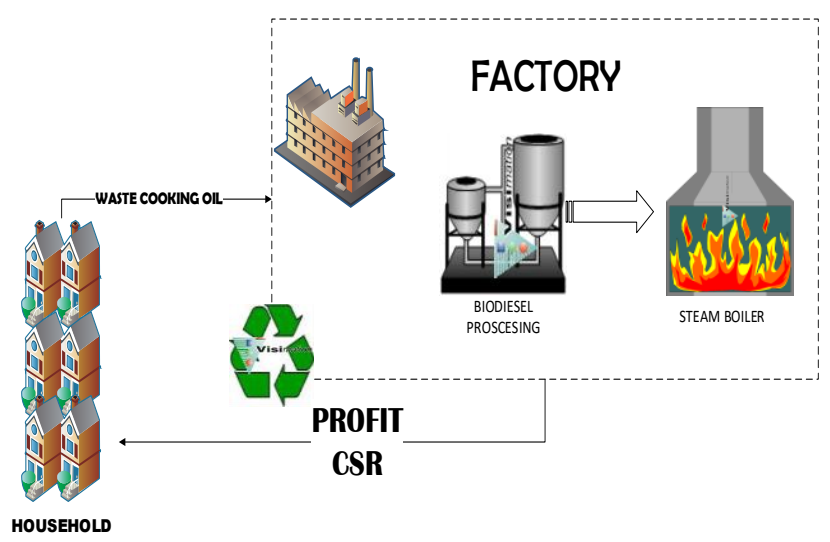

Fig.1. Circular economic diagram 


\section{Results and discussion}

\subsection{Raw Material}

Total population of Semarang is 159,018 people [12] Cooking oil consumption data obtained per capita average is 0.208 litters per week [13]. The amount of used cooking oil that is disposed as waste is $27.61 \%$ of new cooking oil [14], Further semarang barat district potentially produce used WCO as much as 9132 litters per week. The sales scenario of WCO from the neighbourhood is IDR 2000,per Litter [15].

\subsection{Biodiesel Production}

Conducted testing of free fatty acid levels of WCO, obtained the following results:

Table 1. FFA Analysis

\begin{tabular}{|l|l|l|l|}
\hline parameter & Rep.1 & Rep.2 & Rep.3 \\
\hline FFA & $1,32 \%$ & $1,29 \%$ & $1,35 \%$ \\
\hline
\end{tabular}

FFA levels are less than $2 \%$ so that biodiesel production without going through esterification reaction [16]. The level of FFA cooking oil standard distributed according to SNI (Standard National Indonesia) is $<0.3 \%$, even the result after nine times of usage showed FFA results $0.393 \%$ [17]

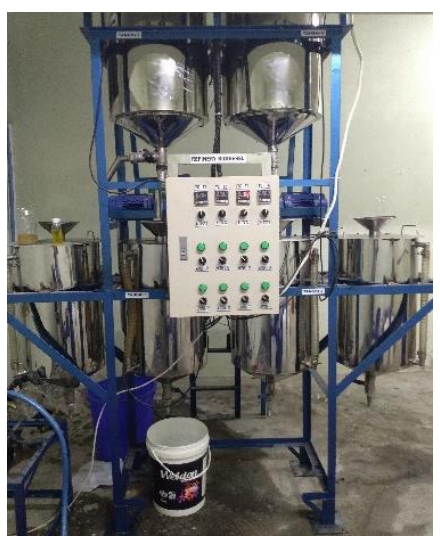

Fig 2. Biodiesel processing machine

Using the machine (Figure 3) obtained biodiesel production of $82.54 \%$, yields and the result of distillation of the remaining methanol obtained $7.8 \%$ methanol that can be recovered. The final quality of biodiesel production results has been compliant with the biodiesel requirements refer to Decree of the Director General of Oil and Gas No.13483K/24/DJM/2006 about the standards and specifications of Biofuels [10].
Table 2. Biodiesel Quality

\begin{tabular}{|l|r|r|r|}
\hline Parameter & Biodiesel & \multicolumn{1}{c|}{$\begin{array}{l}\text { Biodiesel } \\
\text { (Standard) }\end{array}$} & $\begin{array}{l}\text { Diesel } \\
\text { Oil }\end{array}$ \\
\hline Calorie Number (cal/g) & 10.763 & n/a & 10.000 \\
\hline $\begin{array}{l}\text { Flash Point Number } \\
\left({ }^{\circ} \mathrm{C}\right)\end{array}$ & 75,5 & Min 100 & 60 \\
\hline $\begin{array}{l}\text { FAME Concentration } \\
(\%)\end{array}$ & 99,07 & Min 96,5 & $\mathrm{n} / \mathrm{a}$ \\
\hline $\begin{array}{l}\text { Density }\left(\mathrm{kg} / \mathrm{m}^{3}\right) \\
\text { Viscocity }\left(\mathrm{mm}^{2} / \mathrm{s}\right)\end{array}$ & 874 & $850-890$ & $\begin{array}{r}815- \\
860\end{array}$ \\
\hline
\end{tabular}

Based on the test results, biodiesel calorie value is higher than the value of the diesel oil which means higher heat energy emitted from combustion. Flashpoint testing showed $15.5^{\circ} \mathrm{C}$ higher than the diesel oil. Utilized the boiler temperature of lighters that reach $3,000{ }^{\circ} \mathrm{C}$, and biodiesel flashpoint is $75.5^{\circ} \mathrm{C}$ then the burning process become instantly. Viscosity and density affect the ability of fuel spraying into the fog, thus perfect combustion has occurred, the results of density and the viscosity is still within the limits of the specifications have been determined.

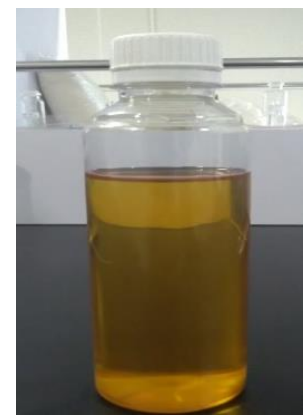

Fig 3. Biodiesel produced

\subsection{Economy Analysis}

The process of biodiesel production with WCO as much as $55.75 \mathrm{Kg}$ (61.91 litters), obtained Cost of Good Manufacturing to with the following table 2:

Table 3. COGM biodiesel

\begin{tabular}{|l|r|l|r|}
\hline Cost Parameter & \multicolumn{2}{|c|}{ Amount/unit } & Total (IDR) \\
\hline Raw Material & 61,911 & liter & 123.822 \\
\hline KOH & 0,55 & $\mathrm{~kg}$ & 13.475 \\
\hline Methanol & 10,8 & liter & 97.200 \\
\hline Water & 0,15 & $\mathrm{~m} 3$ & 600 \\
\hline Direct Labor & & \\
\hline
\end{tabular}




\begin{tabular}{|l|r|l|r|}
\hline Preparation & 2 & hour & 22.500 \\
\hline transesterifikasi & 3 & hour & 33.750 \\
\hline Washing & 2 & hour & 22.500 \\
\hline Distil & 1 & hour & 11.250 \\
\hline Overhead & \multicolumn{3}{|}{} \\
\hline Energy (electrical) & \multicolumn{3}{|l|}{} \\
\hline Transesterifikasi & 1,94 & KWH & 4.012 \\
\hline Washing & 0,198 & KWH & 614 \\
\hline Drying & 1,94 & KWH & 4.012 \\
\hline Depreciation & & & \\
\hline $\begin{array}{l}\text { Refinery } \\
\text { Biodiesel }\end{array}$ & 1 & per day & 30.822 \\
\hline Water Pump & 1 & per day & 255 \\
\hline Hose & 1 & per day & 548 \\
\hline Jerry Can & 1 & per day & 96 \\
\hline Plastic can & 1 & per day & 375.278 \\
\hline Total Cost (1 batch) & & 7.167 \\
\hline COGM (per liter) & & & \\
\hline
\end{tabular}

Compared with the price of natural gas IDR 7900 per m3, there is still a price savings of IDR 177.021 Per day, but because of biodiesel in the form of fluid in daily practice an obstacle related to the mixing of gases and liquids as fuel. The above advantages can be increased by raising the yield of production, looking for alternative materials with cheap price and enlarge the capacity of production machinery according to the capacity of the boiler used.

\section{Conclusion}

Recycled WCO as biodiesel feedstock in Semarang Barat District is able to produce of IDR 135,542,430 per year profit from the distribution of biodiesel and IDR 14,928,656 annually profit from the sales of crude glycerol, using a circular scenario The economy above. That potency is expected many more companies or industries that implement a circular economy that aims for a sustainable economic concept that works without waste, save resources and synergize with the environment $[8,21]$

\section{References}

The result of the calculation indicates that the biodiesel production price reaches IDR 7.167 per liter. When compared to HSD price IDR 9.600 [18] There are cheaper alternatives using Marine Fuel Oil (MFO) IDR 8.600 per liter but there are some disadvantages such as viscosity and purity of the material (water mixture), so it takes pretreatment process before use, sedimentation and temperature conditioning result in increased costs incurred [19]. With the production scheme as in table 3 then the amount of biodiesel per day that can be produced is 185.7 liter with a profit of IDR 451.808 per day Assuming the boiler is used 24 hours for 300 days then the profit gained by IDR $135,542,430$. The amount is not included in the sale of residual reaction of glycerol, using the machine in a day produced $24.69 \mathrm{Kg}$ crude glycerol production of Biodiesel when sold $€ 0.125$ per $\mathrm{Kg}$ [20] Thus giving additional advantage IDR 14,928,656 (€924.37)

Table 4. Biodiesel production scheme

\begin{tabular}{|c|c|c|c|c|c|c|c|c|c|c|c|c|c|c|c|c|}
\hline \multirow{2}{*}{$\begin{array}{c}\text { Step } \\
\mathbf{S} \\
\end{array}$} & \multicolumn{8}{|c|}{ Day 1(Hours) } & \multicolumn{8}{|c|}{ Day 2(Hours) } \\
\hline & 1 & 2 & 3 & 4 & 5 & 6 & 7 & 8 & 1 & 2 & 3 & 4 & 5 & 6 & 7 & 8 \\
\hline \multicolumn{17}{|l|}{$\begin{array}{l}\text { Prepa } \\
\text { ration }\end{array}$} \\
\hline \multicolumn{17}{|l|}{$\operatorname{trans}$} \\
\hline \multicolumn{17}{|l|}{ Wash } \\
\hline \multicolumn{17}{|l|}{ Distil } \\
\hline \multirow[t]{3}{*}{ Note } & \multicolumn{6}{|c|}{ Batch 1} & & & & & & \multicolumn{5}{|c|}{ Batch 4} \\
\hline & \multicolumn{6}{|c|}{ Batch 2} & & & & & & \multicolumn{5}{|c|}{ Batch 5} \\
\hline & \multicolumn{6}{|c|}{ Batch 3} & & & & & & \multicolumn{5}{|c|}{ Batch 6} \\
\hline
\end{tabular}

1. D. Rutz and J. Rainer, Biofuel Technology Handbook, Version 1. Munich: WIP Renewable Energies, (2007).

2. Pusat Data dan Sistem Informasi Pertanian Sekretariat Jenderal - Kementerian Pertanian, "OUTLOOK KELAPA SAWIT 2016" Pusat Data dan Sistem Informasi Pertanian OUTLOOK KELAPA SAWIT Pusat Data dan Sistem Informasi Pertanian Sekretariat Jenderal-Kementerian Pertanian 2016," (2016).

3. F. Haruhiro, I. Wataru, N. Katsuyuki, P. Joko, T. Hiroe, and K. Genshiro, A Comparative Study of Waste Cooking Oil Recycling Programs in Bogor and Niigata Cities and GHG Emission Reduction by Recycling, no. November 2016, (2015).

4. Sahar,S. Sadaf, J. Iqbal, I. Ullah, H.N. Bhatti, S. Nouren, Habibu-ur-rehman, M. Iqbal, Biodiesel production from waste cooking oil: An efficient technique to convert waste into biodiesel, Sustain. Cities Soc., 41, no. December 2017, pp. 220-226, (2018).

5. W. Sakdasri, R. Sawangkeaw, and S. Ngamprasertsith, Techno-economic analysis of biodiesel production from palm oil with supercritical methanol at a low molar ratio, Energy, 152: 144-153, (2018).

6. E. G. Fawaz and D. A. Salam, Preliminary economic assessment of the use of waste frying oils for biodiesel production in Beirut, Lebanon, Sci. Total Environ., 637-638: 1230-1240 (2018).

7. J. Korhonen, A. Honkasalo, and J. Seppälä, Circular Economy: The Concept and its Limitations, Ecol. Econ., 143, no. January, pp. 37-46, (2018). 
8. C. Weetman, A Circular Economy Handbook for Business and Supply Chains_ Repair, Remake, Redesign, Rethink. London: Kogan Page, (2016).

9. Badan Standarisasi Nasional, SNI 01-3555-1998 Cara Uji Minyak dan Lemak, (1988).

10. DEPARTEMEN ESDM RI DIRJEN MIGAS, Keputusan DIRJEN MIGAS 13483K/24/DJM/2006, Jakarta, (2006).

11. Fangkuai clean Boiler Supplier, Horizontal condensing gas steam boiler. [Online]. Available: https://www.boilermanufactory.com/products/integ rated-condensing-steam-boiler.html. [Accessed: 20May-2019].

12. Dispendukcapil Kota Semarang, Jumlah Peduduk Kota Semarang 2018. [Online]. Available: http://www.dispendukcapil.semarangkota.go.id/stat istik/jumlah-penduduk-kota-semarang/2018-12-02. [Accessed: 18-May-2019].

13. PUSAT DATA DAN SISTEM INFORMASI PERTANIAN SEKERTARIAT JENDRAL, STATISTIK KONSUMSI PANGAN 2018, Jakarta, (2018).

14. E. Kusnadi, Studi potensi pencemaran lingkungan akibat limbah minyak jelantah di kota banda aceh, Banda Aceh, (2018).

15. mega nugraha, Bank Minyak Jelantah Berani Beli Minyak Jelantah Rp 2.000 Per Liter - Tribun Jabar, [Online]. Available: http://jabar.tribunnews.com/2017/09/13/bankminyak-jelantah-berani-beli-minyak-jelantah-rp2000-per-liter. [Accessed: 18-May-2019].

16. Widayat and A. D. K. Wibowo, TEKNOLOGI PROSES PRODUKSI BIODIESEL, Pertama. Semarang: EF Press Digimedia, (2013).

17. D. S. Sopianti, H. Herlina, and H. T. Saputra, Penetapan Kadar Asam Lemak Bebas Pada Minyak Goreng, J. Katalisator, 2, 2: 100 (2017).

18. Pertamina, Daftar Harga BBK Tmt 5 Januari 2019 - PT Pertamina (Persero). [Online]. Available: https://www.pertamina.com/id/newsroom/announcement/daftar-harga-bbk-tmt-5januari-2019. [Accessed: 21-May-2019].

19. H. Poeswanto and A. Yani, PERENCANAAN PEMANFAATAN MARINE FUEL OIL (MFO) SEBAGAI BAHAN BAKAR ENGINE DIESEL MaK, Turbo, 4, 55 (2015).

20. C. A. G. Quispe, C. J. R. Coronado, and J. A. Carvalho, Glycerol: Production, consumption, prices, characterization and new trends in combustion, Renew. Sustain. Energy Rev., 27, no. November 2013, pp. 475-493, (2013).

21. W. R. Stahel, The circular economy, Nature, 531, 7595: 435-438, Mar. (2016). 